\title{
Complete Genome Sequence of Two Isolates of Spiraea Yellow Leafspot Virus (Genus: Badnavirus) From Spiraea x Bumalda 'Anthony Waterer'
}

\section{Robert Alexander Alvarez-Quinto ( $\sim$ alvar419@umn.edu ) \\ University of Minnesota Twin Cities https://orcid.org/0000-0002-8524-0067 \\ Joana Serrano}

University of Minnesota Twin Cities: University of Minnesota Twin Cities

Neil E Olszewski

University of Minnesota Twin Cities Campus: University of Minnesota Twin Cities

\section{Samuel Grinstead}

USDA-ARS National Germplasm Resources Laboratory

\section{Dimitre Mollov}

USDA-ARS Horticultural Crops Research Unit

Ben E Lockhart

University of Minnesota Twin Cities Campus: University of Minnesota Twin Cities

\section{Research Article}

Keywords: Spiraea x bumalda, 'Anthony Waterer', genome sequence, spiraea yellow leafspot virus (SYLSV), Badnavirus

Posted Date: July 14th, 2021

DOl: https://doi.org/10.21203/rs.3.rs-704898/v1

License: (c) (i) This work is licensed under a Creative Commons Attribution 4.0 International License.

Read Full License

Version of Record: A version of this preprint was published at Archives of Virology on January 14th, 2022. See the published version at https://doi.org/10.1007/s00705-021-05336-z. 


\section{Abstract}

Isolates of spiraea yellow leafspot virus (SYLSV) were collected from Spiraea (Spiraea $x$ bumalda) 'Anthony Waterer' plants showing virus-like symptoms including yellow spotting and leaf deformation in Minnesota and Maryland. The complete genome sequence of SYLSV-MN (Minnesota) and SYLSV-MD (Maryland) was 8,017bp in length. The sequences share $95 \%$ of identity at the nucleotide level. Both isolates have the same genome organization containing three open reading frames (ORFs), with ORF3 being the largest encoding the putative polyprotein of $232 \mathrm{kDa}$ with conserved domains including Zinc finger, pepsin-like aspartate protease, reverse transcriptase (RT), and RNase H. Pairwise comparisons between members of the genus badnavirus showed that Gooseberry vein banding associated virus GB1 (HQ852248) and Rubus yellow net virus isolate Baumforth's Seedling A (KM078034) were the closest related virus sequences to SYLSV sharing $73 \%$ of identity at the nucleotide level. Bacilliform virions with dimensions of $150 \mathrm{~nm} \times 30 \mathrm{~nm}$ were observed in virus preparations from symptomatic but not in asymptomatic plants.

\section{Background}

Spireas (Spiraea spp.) (Fam. Rosaceae) are deciduous shrubs widely cultivated as landscape ornamentals in northern zones because of their winter hardiness. In the late 1990's, through a combination of electron microscopy and molecular techniques, a badnavirus was identified in Minnesota from Spiraea $x$ bumalda plants displaying yellow leafspot symptoms. The virus, tentatively named after the associated symptoms (spirea yellow leafspot virus, SYLSV), was found to be aphid-transmitted and its prevalence reached up to $100 \%$ in commercial nurseries, public plantings, and home gardens [1].

Despite the prevalence of SYLSV, its complete genomic sequence has not yet been determined. This work reports the complete sequence and genome organization of two SYLSV isolates and supports its classification under the Badnavirus genus in the Caulimoviridae.

Between 2018 and 2020, an increase in the occurrence of yellow spot disease of spiraea was observed among commercial nurseries and landscape ornamentals in the Midwestern region of the USA. A total of 52 samples from several cultivars and species of spiraea collected in Minnesota and Maryland were surveyed for the presence of viral diseases in Minnesota and Maryland. Virus indexing was done by transmission electron microscopy (TEM), polymerase chain-reaction (PCR), and reverse-transcription (RT)-PCR. Samples were obtained from commercial nurseries, landscape ornamentals, the Charlotte Partridge Ordway Japanese Garden, and the Minnesota Landscape Arboretum. One SYLSV isolate from Spiraea $x$ bumalda 'Anthony Waterer' was selected for genome sequencing from each location (Minnesota and Maryland). Symptomatic plants showed severe virus-like disease symptoms including yellow leaf spots, leaf distortion, and stunting. TEM visualization confirmed the presence of bacilliform virus-like particles in symptomatic plants. 
Virus-like particles were partially purified by extracting 20 grams of leaves in $500 \mathrm{mM}$ sodium phosphate (pH 7.5), containing $1 \mathrm{M}$ Urea, $4 \%(\mathrm{w} / \mathrm{v}$ ) polyvinylpyrrolidone (Avg. Mol. Wt 40,000) and $0.5 \%(\mathrm{v} / \mathrm{v}) 2$ mercaptoethanol. The extract was filtered through cheesecloth and centrifuged at $20,000 \mathrm{~g}_{\max }$ for $20 \mathrm{~min}$. After centrifugation, the supernatant was recovered and layered over a $5 \mathrm{~mL}$ cushion of $30 \%(\mathrm{w} / \mathrm{v})$ sucrose in $100 \mathrm{mM}$ sodium phosphate $(\mathrm{pH} 7.0)$ and centrifuged at $109,000 \mathrm{~g}_{\max }$ for 2 hours. The pellet was resuspended in $300 \mathrm{uL}$ of $100 \mathrm{mM}$ sodium phosphate buffer $(\mathrm{pH} 7.0)$, this suspension was clarified by shaking with an equal volume of chloroform and centrifugation at 10,000 $\mathrm{g}_{\max }$ for $15 \mathrm{~min}$. The supernatant constituted the partially purified extract, from which samples were mounted in carbon-coated formvar (1\%) grids and negatively stained with $2 \%$ phosphotungstic acid $(\mathrm{pH} \mathrm{7.0)}$ and examined on a JEOL JEM-1400Plus Transmission Electron Microscope at the University of Minnesota Imaging Center. Bacilliform virions characteristic of the genus Badnavirus were observed in extracts (Fig 1B) from symptomatic but not asymptomatic plants. Virus particles were, on average, $150 \mathrm{~nm}$ in length and $30 \mathrm{~nm}$ in width. No additional virus-like particles were observed on any of the partially purified extracts.

The complete genome sequence of two isolates of SYLSV was determined using two different approaches. Sanger sequencing was used to characterize the virus isolate from Minnesota (SYLSV-MN) and high-throughput sequencing (HTS) was applied for the isolate from Maryland (SYLSV-MD).

SYLSV-MN was sequenced from virion-associated DNA as previously described [2]. PCR was done using the outward-facing primers (SYLSV-Det-R1: 5'- CCATCGACAGCTATCGAATCTGC-3' and SYLSV-Right-1: 5'AGAATTTCAGGAATTTTAGTAGGAGGG-3'), designed from a partial genome sequence of SYLSV (AF299074) corresponding to the RT-RNase $\mathrm{H}$ of the virus [1]. PCR amplicons of approx. $8 \mathrm{~kb}$ were generated and cloned using the TOPO ${ }^{\mathrm{TM}} \mathrm{XL}-2$ Complete PCR Cloning Kit (ThermoFisher) according to manufacturer's instructions. Five clones were sequenced in both directions by primer walking using Sanger technology. An additional PCR product was amplified to confirm a $218 \mathrm{bp}$ region not covered by the outward-facing primers. Three clones of each PCR product $(\sim 1-\mathrm{kb})$ were cloned and sequenced in both directions. The genome assembly was done using Geneious Prime 2021.

The complete genome of the SYLSV was obtained by RNAseq from a symptomatic plant of Spiraea (Spiraea $x$ bumalda 'Anthony Waterer'). Total RNA was extracted using the RNeasy Plant Mini Kit (Qiagen), followed by DNase treatment and ribosomal RNA depletion. A complementary DNA (cDNA) library was generated by TrueSeq and sequenced on a HiSeq 4000 Illumina platform (100bp paired-end reads). Raw data ( $21 \mathrm{M}$ reads) were processed and assembled using CLC Genomic Workbench 11 (Qiagen). A total of 44564 contigs were assembled, from which one was confirmed as SYLSV by Blast analysis.

The viral genome of both isolates consisted of a circular DNA molecule comprising 8,017 bp and 48\% GC content. Sequences were deposited in the NCBI GenBank under accession no. MW080369 and MW080370 for SYLSV-MN and SYLSV-MD, respectively. A genome comparison between the two isolates revealed a $95 \%$ identity, with an identical nucleotide motif complementary to the 3 ' end of the methionine tRNA (5'- TGG TAT CAG AGC TTC GGC -3') as the starting point of the assembled sequences. Prediction 
of putative open reading frames (ORFs) was done using ORfinder (NCBI). The NCBI Conserved Domain search tool was used to identify putative functional domains in the translated protein sequences. The predicted genome organization consisted of three ORFs arranged as those typical of badnaviruses [3, 4]. ORF coding positions in the annotated genomic sequences were the same for both virus isolates, except for ORF3. ORF1 (nt position 399-1055) encodes a putative protein of approximately $24.83 \mathrm{kDa}$, no conserved domains were identified for this putative protein. The protein encoded by ORF1 shares $61 \%$ identity at the amino acid level with gooseberry vein banding associated virus (AEE39274). ORF2 (nt position 1059-1520) codes for a hypothetical protein of $14.13 \mathrm{kDa}$ with no conserved domains detected. The shared identity level between SYLSV-MN and SYLSV-MD in ORF2 is $92 \%$ at the amino acid level. The ORF2-encoded protein shows the highest level of identity (48\%) with gooseberry vein banding associated virus (AEE39278). ORF3 encodes a putative polyprotein of $232.5 \mathrm{kDa}$ with conserved domains identified including zinc finger, pepsin aspartate-like protein, reverse transcriptase (RT), and RNase H. Coding nucleotide positions for ORF3 are 1,459 to 7,596 for SYLSV-MD and 1,457 to 7,594 for SYLSV-MN. The identity of ORF3 between both virus isolates is $97 \%$ at the amino acid level. Pairwise comparisons of the translated protein sequence of ORF3 with other members of the genus badnavirus showed the highest identity with gooseberry vein banding virus - YP_006495799 (67\%, aa level) and Rubus yellow net virus AHB61260 (61\%, aa level). Additional pairwise alignments using the RT+RNase $\mathrm{H}$ region ( 900 bp, defined as one of the criteria for species demarcation) showed the highest identity (73\%) at the nucleotide level with Gooseberry vein banding associated virus.

The phylogenetic relation between SYLSV and members of the genus Badnavirus was studied using selected badnavirus sequences from the NCBI database. Phylogenetic inference was done using the polyprotein (ORF3) amino acid sequence (Fig 2). Sequence alignment was done using the MAFFT algorithm implemented in Geneious Prime. A maximum-likelihood tree was generated using the RaxML algorithm on Geneious Prime. The resulting ML-tree grouped SYLSV-MN and SYLSV-MD in a clade that shares a common ancestor with gooseberry vein banding associated virus and rubus yellow net virus.

In this study, the complete genomic sequence of two isolates of SYLSV was determined. Genome organization and sequence comparison support the conclusions from a previous study, where the existence of a new badnavirus species, in co-infections with a spherical dsRNA virus, was reported from symptomatic Spirea (Lockhart and Geering 2002). During this work, however, TEM and molecular analyses failed to detect the dsRNA virus in samples collected from symptomatic spirea in Minnesota and Maryland, while SYLSV was easily detectable by both approaches. This finding suggests that SYLSV can induce symptoms without the presence of the co-infecting spherical dsRNA virus reported previously. Unlike typical badnaviruses, which are transmitted by mealybugs, SYLSV is transmitted by the aphid Aphis spaericola through an unknown mechanism [1]. High populations of $A$. spaericola were observed during the sampling process of this study.

\section{Declarations}

\section{Funding}


This work was supported by the USDA National Institute of Food and Agriculture, Hatch project \#1009997 and the University of Minnesota, Twin Cities. Alvarez-Quinto R.A is supported by the Republic of Ecuador through the Ecuadorean Science and Technology Secretariat (SENESCYT).

\section{Ethics declarations}

\section{Conflict of interest}

All of the authors declare that they have no conflict of interest.

\section{Ethical approval}

This article does not contain any studies with human participants or animals performed by any of the authors.

\section{References}

1. Lockhart BEL, Geering ADW (2002) Partial characterization of two aphid-transmitted viruses associated with yellow leafspot of Spiraea. Acta Hortic 568:163-168.

https://doi.org/10.17660/ActaHortic.2002.568.24

2. Alvarez-Quinto RA, Lockhart BEL, Olszewski N (2019) Complete genome sequence of a previously undescribed badnavirus occurring in Polyscias fruticosa L. (Ming aralia). Arch Virol 164: https://doi.org/10.1007/s00705-019-04307-9

3. Teycheney PY, Geering ADW, Dasgupta I, et al (2020) ICTV Virus taxonomy profile: Caulimoviridae. J. Gen. Virol. 101:1025-1026

4. Geering ADW (2021) Badnaviruses (Caulimoviridae). In: Bamford DH, Zuckerman M (eds) Encyclopedia of Virology, Academic P. Elsevier, Oxford, pp 158-168

\section{Figures}
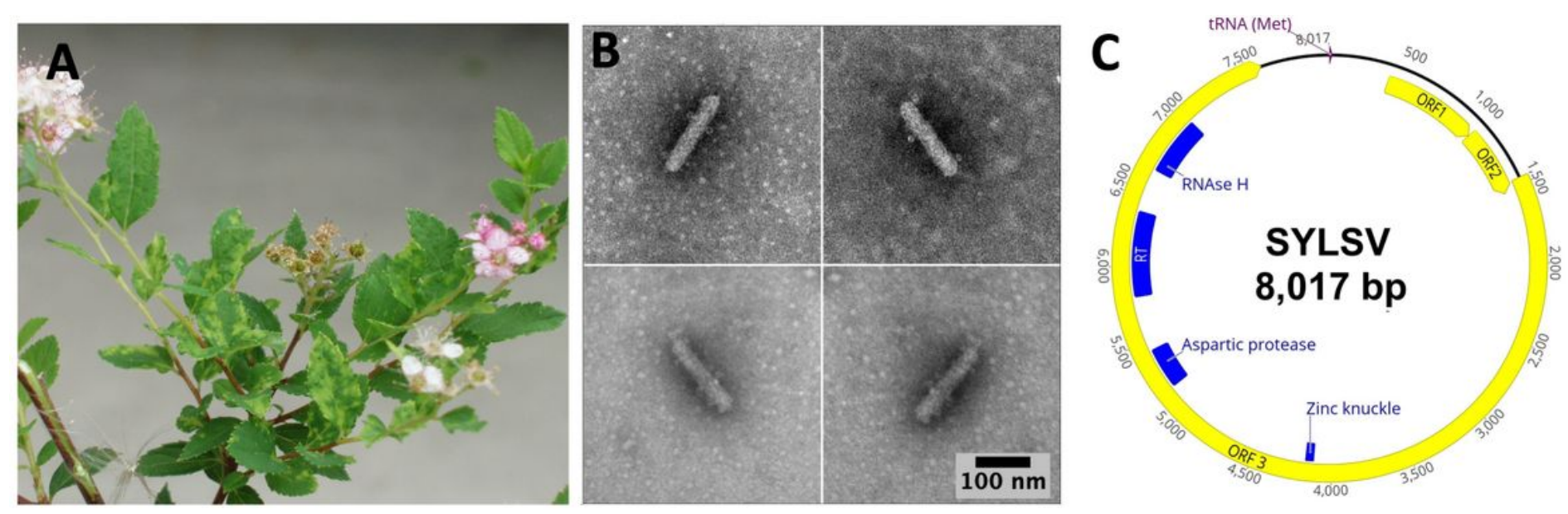

Figure 1 
A. Spiraea plant showing yellow leafspot symptoms associated to SYLSV. B. Virus particles observed in the TEM, scale bar equals $100 \mathrm{~nm}$. C. Graphic representation of the genome of Spirea yellow leafspot virus (SYLSV). The yellow boxes indicate the predicted open reading frames (ORFs), and conserved domains are indicated by overlaying blue boxes.

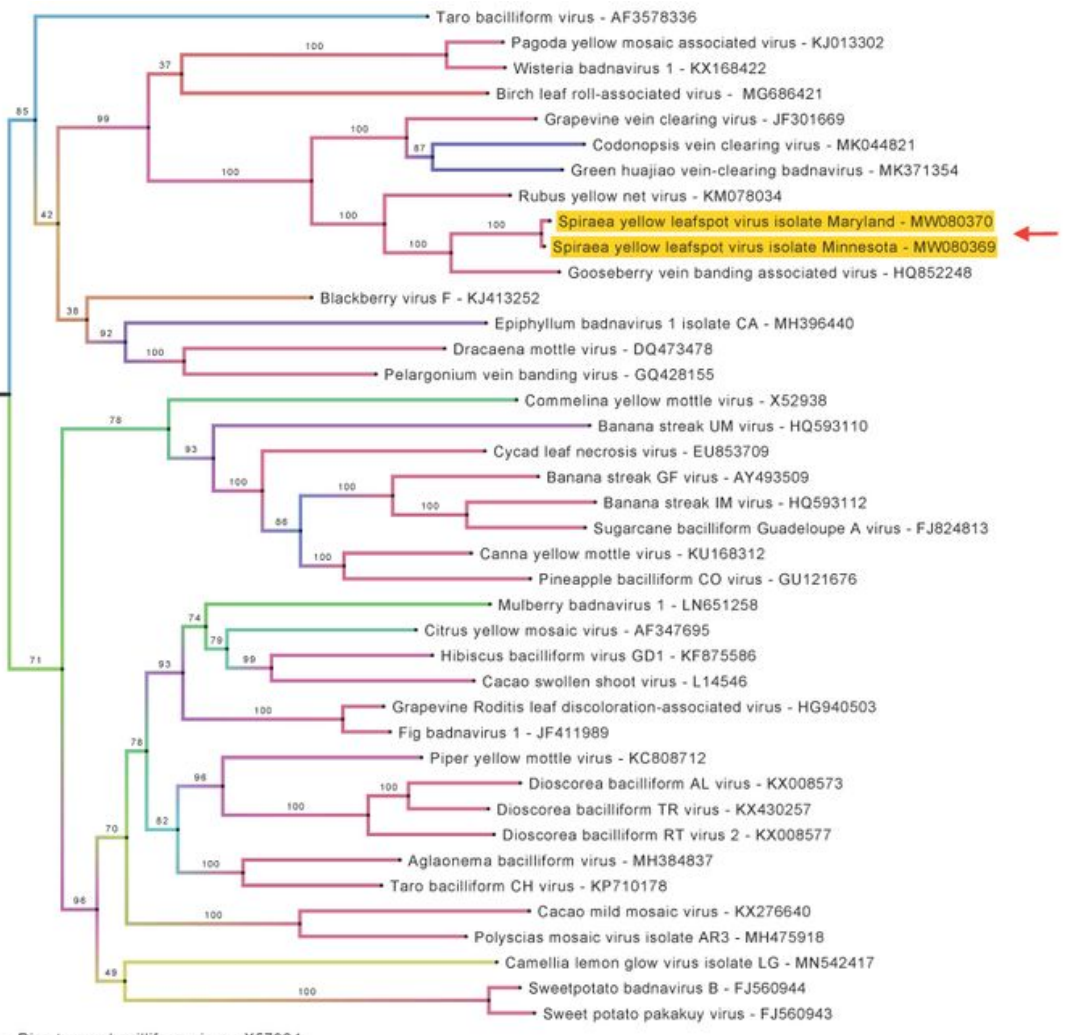

\section{Figure 2}

Maximum-likelihood (ML) phylogenetic tree estimated using the RaxML algorithm implemented in Geneious Prime 2021. Bootstrap values (1000 replicates) are shown at each node. The tree is drawn to scale, with branch lengths expressed in number of substitutions per site. The arrow indicates the position of spiraea yellow leafspot virus. Rice tungro bacilliform virus (genus Tungrovirus) was used as an outgroup.

\section{Supplementary Files}

This is a list of supplementary files associated with this preprint. Click to download.

- SYLSVMN.fasta

- SYLSVMD.fasta 